$1 \mathrm{P} 025$

\section{蛋白質複合体の高圧放射光 $\mathrm{X}$ 線小角散乱データに対するグ ローバルフィット解析}

Global fit analysis on high pressure synchrotron small-angle $x$ ray scattering data of protein complexes

Tetsuro Fujisawa ${ }^{1,2}$, Keiichi Kameyama ${ }^{1}$, Ryo Ishiguro ${ }^{1,2}$ ( ${ }^{1}$ Department of Chemistry and Biomolecular Science, Faculty of Engineering, Gifu University, ${ }^{2}$ RIKEN SPring-8 Center)

Small-angle scattering (SAS) from protein solutions now retrieves distinct structures in solution as an ensemble by rigid body ensemble fitting. Together with other structural methods, these SAS models appears to be "real" in solution. However, it is true that the fitting is susceptible to the quality of data and modeling method. Alternative approaches are required to reinforce this methodology. The combinational use of high hydrostatic pressure (HP) below 400MPa with SAS seems promising, since it enables that the free energy contribution on protein stability and equilibrium can be finely tuned without breaking covalent bonds. We discuss the theoretical foundations of global fitting and its application on high-pressure SAS data.
Effects of organic solvents on the properties of fluorescent proteins

Hideaki Konishi, Suguru Asai, Kunio Takeyasu, Shigehiro Yoshimura (Kyoto university)

Fluorescent properties of fluorophores are known to be affected by the environment (e.g. $\mathrm{pH}$ and permittivity of solvent). The properties of fluorescent proteins (FPs) are also affected in a complicated manner due to their unique chromophore structures. Here, the fluorescent properties of various FPs were elucidated in different hydrophobic environments. The fluorescence intensities of ECFP and EGFP, but not mRFP and mCherry, were decreased in 2,2,2-trifluoroethanol (TFE)-containing solution, whereas lower alcohols had almost no effect. Molecular dynamics revealed that the addition of TFE induced a significant conformational change in the chromophore structure of ECFP.
$1 P 026$ 放射光広角散乱法によるタンパク質熱転移に対する crowding 効果の研究

Crowding effect on thermal transition of proteins clarified by SR-WAXS

Kazuki Takeuchi, Mitsuhiro Hirai (Graduate School of Engineering, Gunma University)

Synchrotron radiation wide-angle X-ray scattering (SR-WAXS) method is useful to detect the structural characteristics of proteins depending on different hierarchal structure levels. On the other hand, crowding environment in cells is assumed to affect structure and function of proteins through the change of chemical potential of water. By using SR-WAXS, we have been studying the thermal stability of proteins under crowding condition generated by the presence high- and/or low-molecular weight neutral molecules as co-solutes. The co-solutes used were polyvinylpyrrolidone (Mw. 40,000) and glycerol. SR-WAXS measurements were performed at SPring- 8 and PF. We will discuss about the difference of crowding effect on the thermal transition feature depending on co-solutes.

\section{硬骨魚類の乳酸脱水素酵素活性の温度依存性}

Thermal stability of lactate dehydrogenase of marine teleostei: molecular adaptation of ectothermic animal to low temperature

Mizuki Nakagawa ${ }^{1}$, Mika Yonezawa ${ }^{1}$, Shigeyoshi Nakamura ${ }^{2}$, Shun-Ichi Kidokoro $^{2}$, Hideki Wakui ${ }^{1}$, Wataru Nunomura ${ }^{1}$ ('Life Sci., Grad. Sch. Eng. \& Resource Sci., Akita Univ., ${ }^{2}$ Dept. Bioeng., Nagaoka Univ. Tech.)

To understand adaptation of exothermal animals to low temperature, we highly purified lactate dehydrogenase (LD) from muscle of slime flounder (Microstomus achne), a bottom-dwelling fish living in $10^{\circ} \mathrm{C}$ sea. The slime flounder muscle contained homogenous single isoform LD at the position of $\mathrm{M}_{2} \mathrm{H}_{2}$ LD isozyme of bovine muscle. The activity of LD was lost at $62^{\circ} \mathrm{C}$ (thermostability). Although the maximum activity of LD was measured at $30^{\circ} \mathrm{C}$, the values of $K_{\mathrm{m}}$ and $V_{\max }$ were increased dependent with temperature between $5^{\circ} \mathrm{C}$ and $40^{\circ} \mathrm{C}$. Differential scanning calorimetry (DSC) measuring revealed that the each subunit of LD simultaneously denatured by heat. We discuss about the relationship between enzyme activity and evolution of ectothermy to endothermy based on the present study.
$1 \mathrm{P029}$

\section{神経小胞融合過程におけるシナプトタグミンと SNARE の分 子機構}

molecular mechanism of synaptotagmin and SNARE in the synaptic vesicle fusion process

Yasuhito Nagai, Tadashi Takemori (Grad. Sch. Pure and appl sci., Univ. Tsukuba)

Synaptotagmin (Syt) family proteins play crucial roles in synaptic vesicle fusion. They have a peculiarly intriguing universal structure of tandem $\mathrm{C} 2$ domains with a flexible linker of a highly conserved length in between, but its role is still unresolved. Points of contact between Syt-I and SNAP25 have been revealed, but the strength of molecular binding seems modest at those binding sites. We shall report molecular dynamics simulation of the interaction between Syt-I and SNARE complexes, to examine the mode of binding between various parts, and to figure out how they can work in concert to assist SNARE formation on the synaptic cell membrane. We shall present a model of the sequence of events leading up to SNARE formation prior to vesicle fusion.

\section{P030ＰLC- 81 PH ドメインの分子内アロステリー \\ Intramolecular allostery in the PLC- $\delta 1$ PH domain}

Michikazu Tanio, Katsuyuki Nishimura (Institute for Molecular Science)

Protein activities are generally regulated by intramolecular allosteric interactions, by which spatially separated sites in a protein molecule communicate. Molecular mechanisms of intramolecular allosteric interactions in the phospholipase $\mathrm{C}(\mathrm{PLC})-\delta 1$ pleckstrin homology $(\mathrm{PH})$ domain were investigated. Mutational analyses using native PAGE and solution NMR methods provide evidence for intramolecular interactions in the PLC- $\delta 1 \mathrm{PH}$ domain, the function of which could be allosterically regulated by modifications at sites spatially separated from the ligandbinding site through the intramolecular interaction network. 